\title{
EFFECT OF MICRO POLYPROPYLENE FIBRE ON THE PERFORMANCE OF FLY ASH-BASED GEOPOLYMER CONCRETE
}

\author{
RAJAK Manoj a, RAI Baboo ${ }^{\text {a* }}$ \\ a National Institute of Technology, Patna-800005, Bihar, India, e-mail: * baboo.rai@ nitp.ac.in
}

Received: 06.02.2019 / Accepted: 21.03.2019 / Revised: 23.04.2019 / Available online: 31.05.2019

DOI: 10.2478/jaes-2019-0013

KEYWORDS: Geopolymer, Polypropylene Fibre, Modulus of Elasticity, Sorptivity, Acid Resistance

\begin{abstract}
:
Geopolymer offers significant promise to the construction world as a possible alternative to ordinary Portland cement (OPC). Like conventional Portland cement concrete, the matrix brittleness in geopolymer composites can be reduced by introducing suitable fibre reinforcement. A few investigations on fibre reinforced geopolymer composites are available. However there is still a gap to comprehend and enhance their performance. This paper describes the effect of incorporating micro polypropylene fibres on the strength and durability characteristics of geopolymer concrete. The engineering and durability properties like workability, compressive strength, split tensile strength, flexural strength, modulus of elasticity, and sorptivity of geopolymer concrete reinforced with micro polypropylene fibres is presented. The effect of the sulfuric acid attack on Geopolymer Concrete reinforced with micro polypropylene fibres is also discussed. The results show that hydrophobic characteristics of the micro polypropylene fibre led to weak contact with the geopolymer binder and hence weakened the mechanical performance of the fly ash based geopolymer matrix. However significant improvements in durability properties were noted.
\end{abstract}

\section{INTRODUCTION}

Fly Ash-based Geopolymer Concrete (FAGC) is earning significant attention in recent years due to its potential application as an alternative binder to ordinary Portland cement (OPC) in the production of concrete with enhanced sustainability and low environmental impact (Juenger et al., 2011). Geopolymer also presents several advantages in terms of early strength development and superior chemical resistance. Apart from several advantages, geopolymers show excessive shrinkage although lesser than Portland cement materials, it is a crucial factor and needs to be considered (Kuenzel et al., 2012; Zuhua et al., 2009; Ridtirud et al., 2011). Moreover, Geopolymer Concrete (GPC) is reported to have less modulus of elasticity as compared to conventional concrete (Fernández-Jiménez et al., 2006; Sofi et al., 2007; Olivia and Nikraz, 2012; Hardjito et al., 2008) for similar compressive strength at 28 days. This is another crucial factor which also needs to be addressed in case of geopolymers. Yost et al. (Yost et al., 2013) found $11-16 \%$ less elastic modulus of FAGC than the theoretical value predicted using ACI 318. Moreover, the inherent brittleness of matrix presents shortcomings very similar to OPC concrete.

Nowadays, fibre-reinforced composite materials, including those produced by alkali-activated materials, assume a fundamental role in numerous parts of the business, e.g., in cutting innovative edge arrangements utilized in the aviation and car industry, maritime design and ground transportation (Shaikh, 2013a; Natali et al., 2011). They have many advantages in comparison to traditional materials. Past researches have shown the encouraging performance of fibre reinforced OPC cement concrete. Incorporation of fibres into the cementitious matrix fibre controls the crack propagation when subjected to tension or flexion stresses (Puertas et al., 2003; Bernal et al., 2010) and hence is an efficient method to enhance the flexural and toughening mechanisms properties of corresponding composites. The use of fibre to improve the brittleness of GPC is comparatively new compared to conventional concrete. There have been a few studies carried out in the area of Fibre Reinforced Geopolymer Concrete (FRGC).

Davidovits (Davidovits, 2005; Davidovits, 1994; Davidovits, 1991) was the first to synthesize fibre reinforced geopolymer concrete for their use in the plastic processing industry. This was furthermore extended by various other researchers, utilizing particular sorts of fibres, for instance, carbon and glass(Natali et al., 2011), polyvinyl alcohol (PVA) (Yunsheng et al., 2008; Nematollahi et al., 2015) polypropylene (PP) (Li et al., 2016), polyethylene (PE) (Nematollahi et al., 2017; Ahmed and Ronnie, 2017) and steel fibers (Gao et al., 2017; Ranjbar et al., 2016b; Li et al., 2016; Bernal et al., 2010; Ranjbar et al., 2016c) in a diverse range of geopolymers containing different source materials and alkaline solutions (Shaikh, 2013b). Subsequent, reinforcement of geopolymers with different type of fibres were carried on through protein-based fibres 
(Alzeer and MacKenzie, 2012), basalt fibres (Dias and Thaumaturgo, 2005), organic fibres like cotton, flax, etc. (Alomayri et al., 2014; Assaedi et al., 2016) and carbon fibres (Ranjbar et al., 2015; He et al., 2010) to overcome the brittleness and abysmal failure of the matrix.

Polypropylene fibre (PPF) is chemically inert and thermally stable in the alkaline environment of concrete. The low cost and ease of dispersal make them suitable for incorporation in concrete (Kalifa et al., 2001; Banthia and Gupta, 2006). Polypropylene fibre because of its high toughness and durability has been extensively used as reinforcement in Portland cement-based materials; despite the fact that there is a conflict about the PPF content and the corresponding compressive strength of the concrete. Incorporation of PPF in the concrete matrix substantially reduces the compressive strength of concrete (Alhozaimy et al., 1996; Aulia, 2002). The same has also been stated in a report published by the Building Research Establishment (BRE, 2000). However, incorporation of PPF is claimed to improve durability by enhancing concrete's performance with regard to high impact resistance; increased strain to failure; more water permeable resistant (Richardson, 2006).

Contrary to others Reed et al. (Reed et al., 2014) reported an increase in compressive strength of polypropylene fibre reinforced geopolymer concrete. However, a decrease in compressive strength was also reported at a higher volume of PP fibre. Heard et al. (Heard et al., 2011) investigated the properties of bundled monofilament polypropylene fibre reinforced geopolymer concrete (FRGPC). The author through his exploratory research concluded that PP fibres have the potential for global ductility enhancement by increasing the fibre-matrix bond strength. He further concluded that PP fibres are accountable for crack bridging and slippage before fibre failure.

The present study compares the influence of variable dosages of micro PPF used in FAGC on controlling of surface permeability, i.e. sorptivity and mechanical properties of the FAGC. The scope of this project also involves a comparison of the performance of conventional concrete, FAGC and PFRGC after acid attack. The effect of the acid attack was assessed by immersing concrete cubes in 5\% solution of sulfuric acid up to 56 days. Visual appearance, change in weight and change in compressive strength before and after exposure were used as a parameter to assess the behaviour of reference concrete, FAGC and PFRGC.

\section{MATERIALS AND METHODS}

\subsection{Material and Their Properties}

The materials used in the present investigation were locally availed, and physical properties were found through various laboratory tests. The low calcium Fly Ash (FA) used in this research has been collected from Kahalgaon Thermal Power Plant, Bihar, India and satisfies ASTM class F classification. The chemical properties as supplied by the Kahalgaon Thermal Power Plant is presented in Table 1 and satisfies the requirements of Indian Standards IS: 3812, 2003 (IS 3812 : Part 1, 2003).

Table 1. Chemical Properties of Fly Ash

\begin{tabular}{lll}
\hline $\begin{array}{l}\text { Sl. } \\
\text { No. }\end{array}$ & Test Conducted & $\begin{array}{l}\text { Observed } \\
\text { value }(\%)\end{array}$ \\
\hline 1 & Loss of Ignition & 2.53 \\
2 & Silica as $\mathrm{SiO}_{2}$ & 59.51 \\
3 & $\mathrm{SiO}_{2}+\mathrm{Al}_{2} \mathrm{O}_{3}+\mathrm{Fe}_{2} \mathrm{O}_{3}$ & 86.85 \\
4 & Available Alkalis as $\mathrm{Na}_{2} \mathrm{O}$ & 0.43 \\
5 & Reactive Silica & 29.32 \\
6 & Magnesium as $\mathrm{MgO}$ & 1.97 \\
7 & Sulphate as $\mathrm{SO}_{3}$ & 2.07 \\
8 & Total Chloride & 0.032 \\
9 & Lime Reactivity & $4.9 \mathrm{~N} / \mathrm{mm}^{2}$ \\
\hline
\end{tabular}

The sodium hydroxide $(\mathrm{NaOH})$ was obtained from the local market in the form of Pellets with a specific gravity of 2.13 and the purity of $97 \%-98 \%$. The pellets were dissolved in distilled water. The mass of $\mathrm{NaOH}$ pellets per litre of solution is the concentration of the solution expressed in terms of Molar (M). In the present work, the mass of $\mathrm{NaOH}$ solids per $1000 \mathrm{gm}$ of $\mathrm{NaOH}$ solution for $14 \mathrm{M}$ concentration was taken as $404 \mathrm{gm}$ (Hardjito and Rangan, 2005). Alkaline activator was a mixture of $14 \mathrm{M}$ sodium hydroxide solution and sodium silicate solution at a $\mathrm{SiO}_{2} / \mathrm{Na}_{2} \mathrm{O}$ ratio by mass of $2\left(\mathrm{SiO}_{2}=24.4 \%, \mathrm{Na}_{2} \mathrm{O}=\right.$ $14.7 \%$ and water $55.9 \%$ by mass).

Locally available natural sand and crushed Pakur stone with a nominal maximum size of $20 \mathrm{~mm}$ meeting Indian standard specification (IS 383, 2016) were used as fine aggregate and coarse aggregate respectively. The physical properties of both the aggregates are presented in Table 2.

Table 2. Physical Properties of Coarse and Fine Aggregate

\begin{tabular}{lcc}
\hline Physical properties & Coarse aggregate & Fine aggregate \\
\hline Water absorption $(\%)$ & 0.755 & 1.35 \\
Specific gravity & 2.713 & 2.66 \\
\hline
\end{tabular}

Commercially available micro Polypropylene Fibres (PPF) manufactured by Reliance industry in the name of Recron-3s were used in the present investigation. The specification of polypropylene fibre as available from Building Materials and Technology Promotion Council (BMTPC) ministry of urban employment and poverty alleviation government of India is presented in Table 3.

Table 3. Specification and Physical Properties of Micro PPF

\begin{tabular}{llll}
\hline S. & Properties & Unit & I $^{\text {st }}$ grade \\
\hline 1 & length & $\mathrm{mm}$ & 12 \\
2 & Diameter & $\mathrm{mm}$ & 0.032 \\
3 & Aspect ratio & $1 / \mathrm{d}$ & 375 \\
4 & Density & $\mathrm{g} / \mathrm{cm}^{3}$ & 0.91 \\
\hline
\end{tabular}




\subsection{Geopolymer Synthesis and Mixture proportion}

In the present investigation, the production of geopolymer concrete is carried out using IS: 10262-2009 (IS 10262:2009). The aggregates were allocated in the range of $70 \%$ to $80 \%$ of the total mass of geopolymer concrete. In the previous work (Rai et al., 2018) the production of 50MPa GPC utilized $427 \mathrm{~kg} / \mathrm{m}^{3} \mathrm{FA}, 547$ $\mathrm{kg} / \mathrm{m}^{3}$ fine aggregate and $1276.8 \mathrm{~kg} / \mathrm{m}^{3}$ coarse aggregate. All dry materials were mixed in the pan mixer for about $3 \mathrm{~min}$. The liquid component of the mixture was added at the end of dry mixing, and after that wet mixing was continued for another $4 \mathrm{~min}$.
In the present work, in case of PFRGC mixes, PPF were added to the GPC mix in seven weight fractions such as $0.1 \%, 0.15 \%, 0.2 \%, 0.25 \%, 0.3 \%, 0.4 \%$ and $0.5 \%$ by volume of concrete. The prepared solution of sodium hydroxide of $14 \mathrm{M}$ concentration was mixed with sodium silicate solution one day before mixing the concrete to get the desired alkalinity in the alkaline activator solution. Micro PPF is a multifilament fibre and could not disperse homogeneously in the matrix. Therefore, PPF was mixed with the alkali activator solution and stirred until a uniform dispersion obtained. The mix proportioning of all the trial mixes and their curing condition is given in Table 4 .

Table 4. Mix Proportion of PFRGC

\begin{tabular}{|c|c|c|c|c|c|c|}
\hline $\begin{array}{l}\text { Mix } \\
\text { No. }\end{array}$ & Molarity & $\begin{array}{l}\mathrm{NaOH} / \\
\mathrm{Na}_{2} \mathrm{SiO}_{3}\end{array}$ & $\begin{array}{c}\text { Activator / Fly } \\
\text { Ash }\end{array}$ & $\begin{array}{c}\% \text { of Polypropylene by } \\
\text { weight of FA }\end{array}$ & $\begin{array}{c}\text { PPF } \\
\mathrm{Kg} / \mathrm{m}^{3} \text { of Concrete }\end{array}$ & Curing condition \\
\hline 1 & 14 & 0.40 & 0.35 & 0.00 & 0.00 & \multirow{8}{*}{$\begin{array}{l}\text { Oven curing for } 24 \\
\text { hours at } 80^{\circ} \mathrm{C} \text { Temp }\end{array}$} \\
\hline 2 & 14 & 0.40 & 0.35 & 0.10 & 0.91 & \\
\hline 3 & 14 & 0.40 & 0.35 & 0.15 & 1.37 & \\
\hline 4 & 14 & 0.40 & 0.35 & 0.20 & 1.82 & \\
\hline 5 & 14 & 0.40 & 0.35 & 0.25 & 2.28 & \\
\hline 6 & 14 & 0.40 & 0.35 & 0.30 & 2.73 & \\
\hline 7 & 14 & 0.40 & 0.35 & 0.40 & 3.64 & \\
\hline 8 & 14 & 0.40 & 0.35 & 0.50 & 4.55 & \\
\hline
\end{tabular}

The test specimens were cured in the oven at a temperature of $80^{\circ} \mathrm{C}$ for 24 hours (hrs). The cubes were then left at room temperature for further $24 \mathrm{hrs}$ after which the strength tests were conducted. All the

\subsection{Test Program and Procedures}

\subsubsection{Strength Test}

A Digital Compression Testing Machine of $2000 \mathrm{kN}$ capacity was used for measuring the compressive strength of test specimens. Compressive strength was measured on $150 \mathrm{~mm}$ cubes in accordance with Indian Standard IS 516-1959 (IS: 516, 1959). Three cubes were tested, and average values were obtained.

The load-deflection curves were plotted using the data recorded during the compressive testing of the cylindrical specimens. An extensometer determined the axial displacement of the specimens in the compression testing machine in accordance with ASTM C 469 (ASTM C $469,2014)$. The modulus of elasticity was then obtained from the load-deflection curves.

Cylindrical specimens of size $150 \mathrm{~mm} \times 300 \mathrm{~mm}$ were cast to measure the splitting tensile strength in accordance with Indian Standard IS 5816,-1976 (IS: $5816,1999)$. Three cylinders were tested, and the average values were obtained.

For the flexural strength test, beams were cast in moulds of $50 \times 10 \times 10 \mathrm{~cm}$ dimensions. The flexural strength of concrete beam samples was conducted using centre point loading as per ASTM standards in accordance with parameters like molarity, $\mathrm{NaOH} / \mathrm{Na}_{2} \mathrm{SiO}_{3}$, Activator / Fly Ash ratio has been taken from recently published literature (Rai et al., 2018).

practices mentioned in ASTM C-293-02 (ASTM C29302, 2002).

\subsubsection{Sorptivity Test}

For determining sorptivity, the standard test specimens of $100 \mathrm{~mm}$ diameter disc of thickness $50 \mathrm{~mm}$ were cast. These specimens were tested as per ASTM C1585-13 (ASTM C 1585, 2013) after 28 days. Sorptivity calculations were done in accordance with ASTM C1585-13. The cumulative absorbed volume of water per unit area of inflow surface (I) was related to the square root of the elapsed time $\left(\mathrm{t}^{0.5}\right)$ with the following equation

$\mathrm{I}=\mathrm{s} \times \mathrm{t}^{0.5}$

Where, $\mathrm{S}$ is sorptivity

$I=\frac{M_{r}}{a \times d}$

Where, $\mathrm{I}=$ the absorption, $\quad M_{t}=$ the change in specimen mass in grams, at the time $\mathrm{t}, \mathrm{a}=$ the exposed area of the specimen, in $\mathrm{mm}^{2}, \quad \mathrm{~d}=$ the density of the water in $\mathrm{g} / \mathrm{mm}^{3}$.

\subsubsection{Acid Resistance Test}

There are no broadly established methods for acid resistance test, therefore based on the past studies of Curtin 2006 and Tomkins 2011 (Wallah and Rangan, 2006; Tomkins, 2011) to assess the acid resistance, the test specimens were immersed in $5 \%$ sulfuric acid 
solution with the $\mathrm{pH}$ ranging from about 1.4 to 2.3 up to a period of 56 days of exposure. The $\mathrm{pH}$ was measured with the help of the $\mathrm{pH}$ meter available in the laboratory. The acid resistance of geopolymer concrete was then assessed through visual appearance, change in weight and compressive strength at an interval of 7, 14, 28 and 56 days. The tests were conducted in the saturatedsurface-dry (SSD) condition. The specimens were removed from the acid solution container and wiped clean and after measurement of weight. The specimens were again kept in the acid solution container.

\section{RESULTS AND DISCUSSIONS}

\subsection{Slump Test Results}

All the mixes were generally cohesive and immaculate in appearance due to the presence of the sodium silicate solution. It was observed that the inclusion of polypropylene fibres reduces the slump values. A comparative study of the slump test result of PFRGC is shown graphically in Fig. 1. The slump values were measured immediately after wet mixing in pan mixture. The degrees of workability for all trial mixes were high with an average slump of $130 \mathrm{~mm}$. However, the slump values of the PFRGC shows a decreasing trend. At higher fibre content the rate of decrement in a slump was more significant this may be due to the balling effect of fibres while mixing geopolymer concrete at higher fibre content. Further, dispersion of polypropylene fibre at higher percentage addition in geopolymer concrete mix was difficult which may have led to significant reduction in a slump. However, in the present investigation, the reduced slump of mixes is largely related to the low density of these fibres (approx. $0.91 \mathrm{gm} / \mathrm{cc}$ ). Similar observations are also reported in literature ( $\mathrm{Li}$ et al., 2016; Ranjbar et al., 2016a).

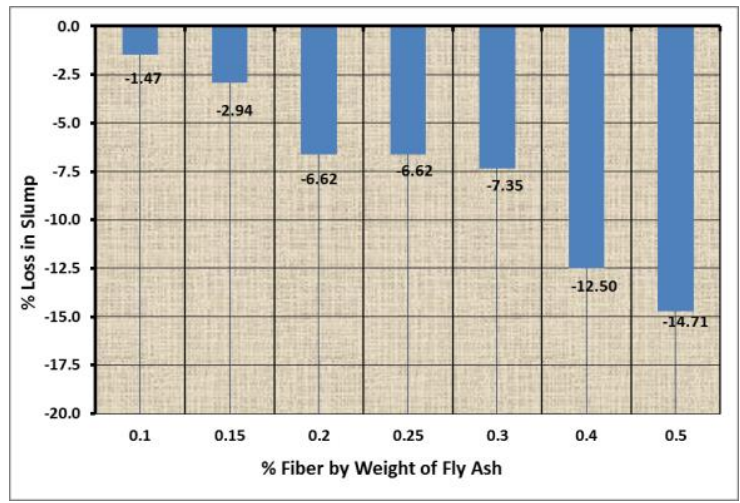

Figure 1. Percentage Loss in Slump

\subsection{Compressive Strength Test}

The effect of micro PPF on compressive strength of geopolymer concrete after oven curing for 24 hours at $80^{\circ} \mathrm{C}$ is graphically represented in Fig. 2 along with the data table. Fig. 3 represents the percentage change in strength at a different weight percentage of PPF. It can be inferred from the graph that on the addition of $0.1 \%$ PPF the loss in compressive strength is approximately is $10 \%$ as compared to GPC without fibre. However, the rate of loss percentage decreases as the PPF addition increases from $0.15 \%$ to $0.2 \%$. At $0.3 \%$ addition of PPF, the compressive strength loss was approximately $12 \%$. Minimum loss of about 5\% in compressive strength was observed at $0.2 \%$ addition of PPF by weight of fly ash. The chemical structure of the polypropylene makes it hydrophobic concerning the cementitious matrix, leading to reduced bonding with the cement, and negatively affecting its dispersion in the matrix (López-Buendía et al., 2013; Li et al., 2016). Micro PPF may have reduced the strength due to the balling effect while mixing, as seen here. The effect of PPF on the compressive strength of concrete has been discussed in many literatures (Parviz Soroushian and Jer-Wen Hsu, 1992; Malhotra et al., 1994; Hua Yuan, Liu Ronghua, 1998; Li Guangwei, 2001). The effect of a low volume of PPF on the compressive strength might be disguised by the experimental error (Gong Yi, Sben Rongxi). However, the results of compressive strength, discussed here are in line with the findings of earlier researchers (Hughes B.P., and Fattuhi., 1976; Zollo; Litvin, 1985; Fanella and Naaman, 1985; Al-Tayyib, A.J., Al-Zahrani, M.M. and A., Al-Sulaimani, 1988). Conflicting outcomes on the compressive quality of FRGCs are accounted for in writing. In a report, Bernal et al. (Bernal et al., 2010) announced a decrease in compressive qualities of steel fibre reinforced slag based FRGC. In another examination on PFRGC, no such lessening in compressive quality is seen (Puertas et al., 2003). The formation of entrapped voids inside the geopolymer composites may have gradually increased with increase in volume fraction of PP fibre suggesting a gradual decrease in compressive strength. A similar reduction in compressive strength of PFRGC composite is also reported (Zhang et al., 2009; Puertas et al., 2003).

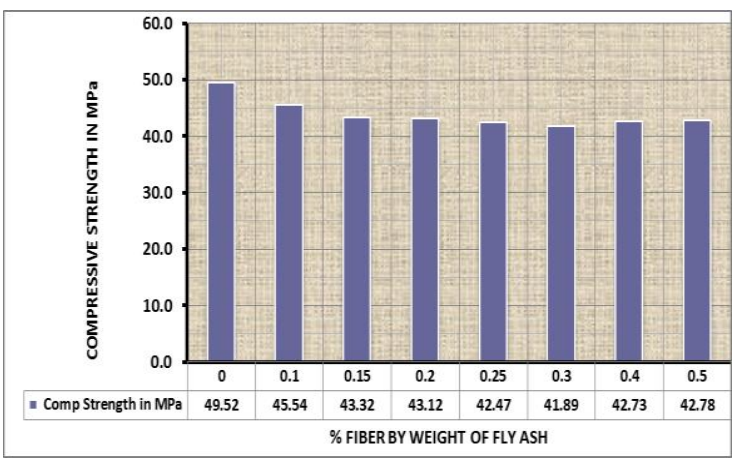

Figure 2. Compressive Strength Test Results

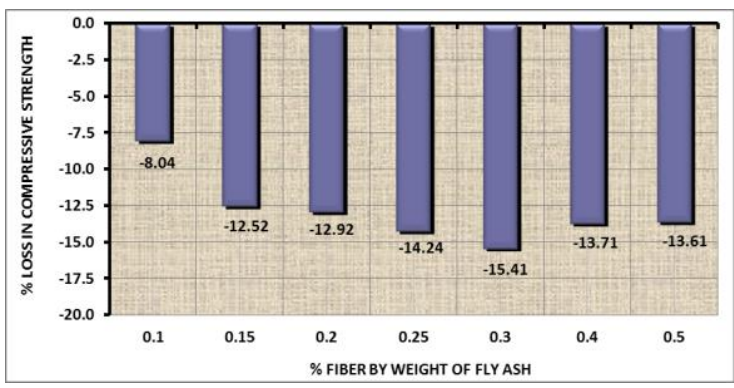

Figure 3. Percentage Change in Compressive Strength 


\subsection{Modulus of Elasticity}

The strains at ten equal load intervals were measured. For each weight fraction of polypropylene fibres, a graph was drawn by plotting the average strains against their corresponding stresses then best fit straight line was drawn through the plotted points. From the best fit straight line equation, the slope of the line is expressed as modulus of elasticity. The effect of the addition of polypropylene fibres on the modulus of elasticity has been investigated and presented. Test results of the modulus of elasticity are presented in Table 5. There is no significant difference in modulus of elasticity, observed by adding PP fibres in GPC mix.

This can also be inferred from Fig. 4 which graphically represents the percentage change in modulus of elasticity at different $\%$ addition of PPF in geopolymer mix. The percentage increase or decrease in modulus of elasticity was observed to be within $2 \%$ with a maximum decrease of about $5 \%$ at $0.5 \%$ PPF by weight of FA. PFRGC containing up to $0.3 \%$ PPF exhibited higher strain capacities. At low volume fractions, the micro PP Fibres may have hampered the crack propagation by bridging the microcracks. However, composites containing higher volume fractions of PPF, $(0.4 \%$ and $0.5 \%)$ showed a decrease in modulus of elasticity. The dispersion of PP fibre at higher volume fraction was difficult (sec 3.1) and hence may have reduced the modulus of elasticity further. Moreover, due to the low density of PP fibre, there is a possibility of formation of fibre balling during mixing at higher volume fraction which may have entrapped voids in the composite (Alomayri et al., 2014).

Table 5. Modulus of Elasticity of PFRGC

\begin{tabular}{ccc}
\hline $\begin{array}{c}\% \\
\text { Polypropylene } \\
\text { Fiber }\end{array}$ & $\begin{array}{c}\text { Compressive } \\
\text { Modulus of } \\
\text { Elasticity } \\
\text { GPa }\end{array}$ & $\begin{array}{c}\text { \% Loss } \\
\text { In Elasticity }\end{array}$ \\
\hline 0.00 & 27.92 & 0.0 \\
0.10 & 27.62 & -1.1 \\
0.15 & 27.53 & -1.4 \\
0.20 & 28.21 & 1.0 \\
0.25 & 28.33 & 1.5 \\
0.30 & 28.44 & 1.9 \\
0.40 & 27.10 & -2.9 \\
0.50 & 26.42 & -5.4 \\
\hline
\end{tabular}

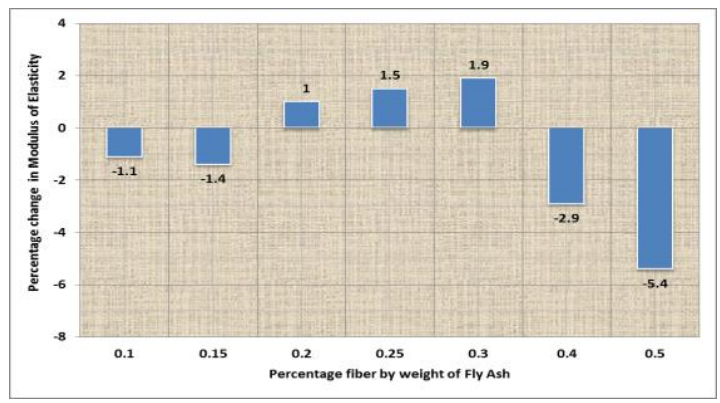

Figure 4. Percentage Change in Modulus of Elasticity of PFRGC

\subsection{Split Tensile Strength Test}

Fig.5 shows the splitting tensile strengths of the PFRGC specimens. From Fig. 5 it can be observed that the values of cylinder splitting-strength ranged between 3 and $4 \mathrm{MPa}$. From Fig. 6 it is clear that the splittingtensile strengths of PFRGC are increasing. The increase was almost $30 \%$ at $0.5 \%$ addition of polypropylene fibre by weight of fly ash.

Direct tensile strength calculated by split tensile strength does not give fair idea due to mixed stress field and fibre alignment. However, its failure mode contributes to the analysis of the ductility of the concerned material. Fig. 7 clearly shows that the specimen does not split out from each other, unlike the FAGC. Stress transfer mechanism due to Fiber bridging action is accountable for such heightened ductile failure pattern. The same has been reported by Song and Hwang, 2003 (Song and Hwang, 2004) and Roohollah et al., 2012 (Bagherzadeh et al., 2012).

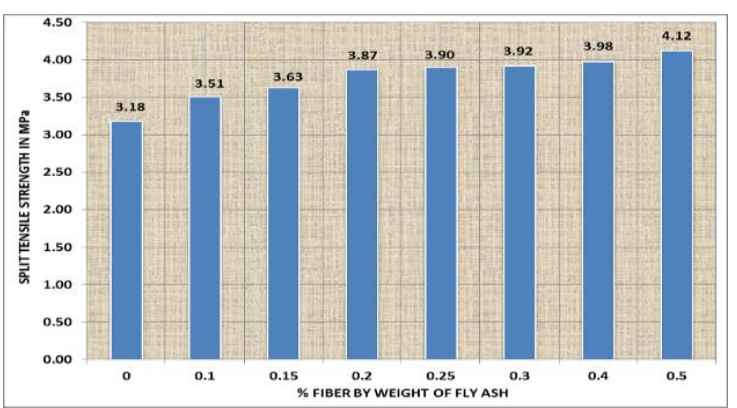

Figure 5. Split Tensile Strength Test Results

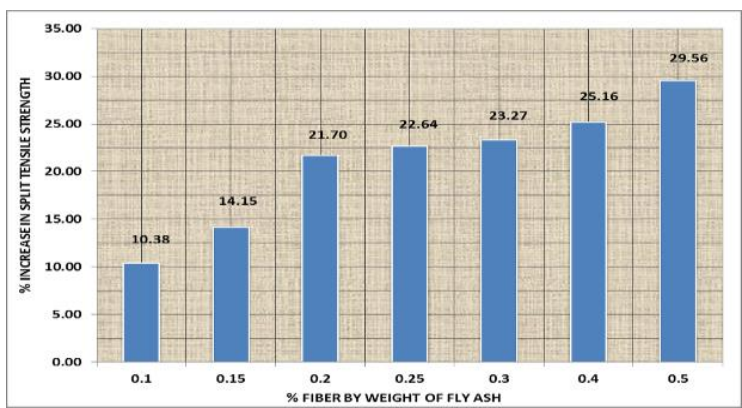

Figure 6. Percentage Gain in Split Tensile Strength

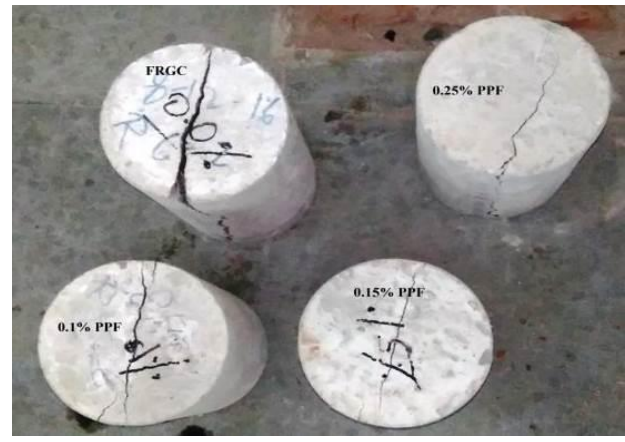

Figure 7. Fracture Mode after Split Tensile Strength 
The flexural strength of PFRGC beam samples was conducted using center point loading as per ASTM standards in accordance with practices mentioned in ASTM C-293-02. The comparative test results are presented in Fig.8 and Fig.9. The result shows that the flexural strength of PFRGC increases with the increase in PPF. From Fig. 8 it can be inferred that the flexural strength range between 5.5 and $7 \mathrm{MPa}$.

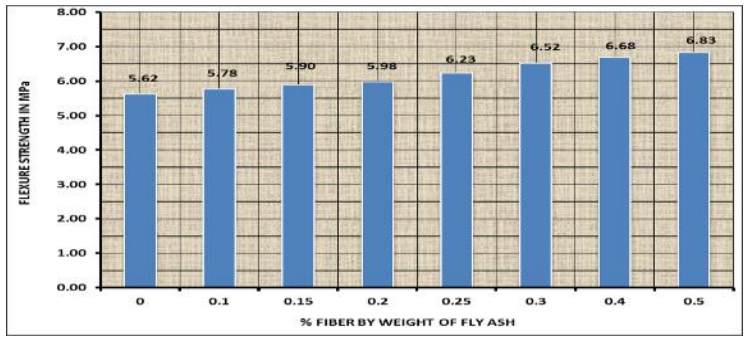

Figure 8. Flexural Strength Test Results

From Fig. 9 it can be inferred that at $0.3 \%$ addition of polypropylene fibre in the concrete mix the percentage increase in flexural strength observed was nearly $16 \%$ as compared to control GPC mix. Previous work (Ranjbar et al., 2016a) also reported the same trend of flexural strength gain up to $0.3 \%$ fibre addition in GPC. It has been further reported that as the content of PP fibre in the geopolymer concrete matrix increases beyond $0.3 \%$ there is an increase in porosity which leads to a reduction in the rate of increment of flexural strength.

From literature (Perera et al., 2007) it is well known that geopolymer shrinks excessively during heat curing. This excessive shrinkage may lead to the formation of micro cracks. The induction of micro PP fibre in the geopolymer concrete matrix reduces the probability of formation of micro-cracks during the plastic stage and hence makes the PFRGC mixes more flexure. Further, it has been reported (Komonen and Penttala, 2003; Urbanova et al., 2007) that PP fibre stretches themselves to accommodate the crack face separation thus providing an extra energy absorbing mechanism which might have helped in improving the flexural strength of PFRGC.

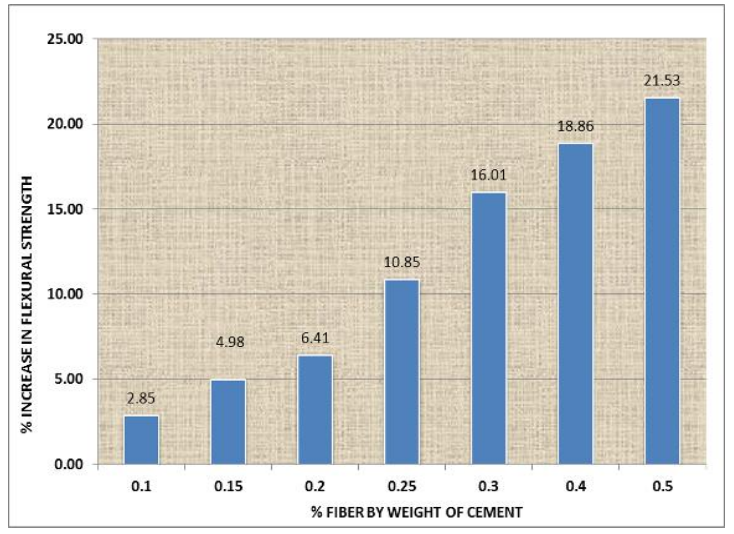

Figure 9. Percentage Gain in Flexural Strength

\subsection{Sorptivity Test Results}

The slope of the line that is the best fit to I plotted against the Square root of time $\left(\mathrm{s}^{1 / 2}\right)$ obtained by using linear regression analysis is the water absorption in $\mathrm{mm} / \mathrm{s}^{1 / 2}$. For the regression analysis, all the points measured up to $6 \mathrm{hrs}$ are used, If the data between $1 \mathrm{~min}$ and $6 \mathrm{hrs}$ do not follow a linear relationship (a correlation coefficient of less than 0.98) and show a systematic curvature, the initial rate of absorption cannot be determined. The sample graphs of the depth of water absorption (I, mm) versus square root of time for all specimen of PFRGC were plotted (Fig. 10), from which initial sorptivity were determined by using Equations 3, respectively.

$$
I=S_{i} \sqrt{t}+b
$$

Where: $S_{i}=$ initial rate of absorption in $\mathrm{mm} / \sqrt{\mathrm{s}}$

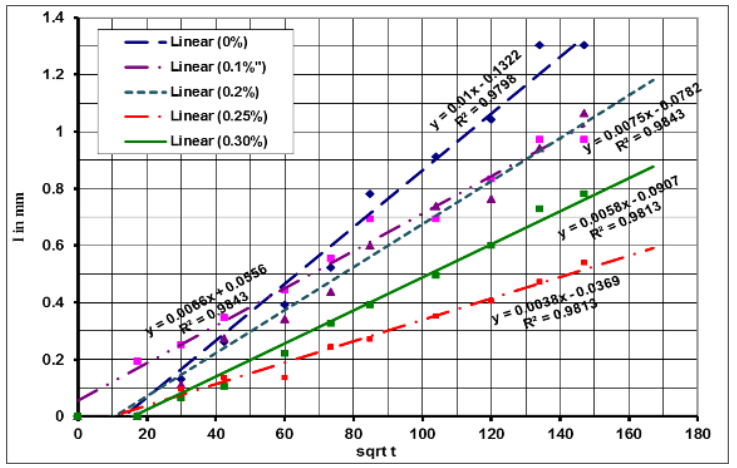

Figure 10. I versus $\sqrt{t}$

The I versus $\sqrt{t}$ graph show that for all the specimens the initial slope is practically identical further, for all samples tested, the relationship between $I \& \sqrt{t}$ begins to deviate from linearity after 30 minutes. Sorptivity is an index for concrete durability and reduces with increase in fibre content.

Test results have shown that surface permeability has decreased under the stressed conditions with the use of $\mathrm{PPF}$, preventing restriction from cracks and preventing water easily entering in concrete thus indicating a significant reduction in capillary porosity. Table 6 depicts the sorptivity test result for PFRGC respectively. Fig. 11 shows that as PPF increases concrete sorptivity decreases. The graph of initial sorptivity versus percentage of PPF also represents a linear relationship between high $\mathrm{R}^{2}$ values and is shown in Fig. 11.

Table 6. Sorptivity Test Results for PFRGC

\begin{tabular}{|c|c|c|c|}
\hline $\begin{array}{c}\% \\
\text { PPF }\end{array}$ & $\begin{array}{c}\text { Sorptivity } \\
\text { Sample 1 } \\
\left(\mathrm{m}^{*} \mathrm{~s}^{-0.5}\right)\end{array}$ & $\begin{array}{c}\text { Sorptivity } \\
\text { Sample 2 } \\
\left(\mathrm{m}^{*} \mathrm{~s}^{-0.5}\right)\end{array}$ & $\begin{array}{c}\text { Avg } \\
\text { Initial Sorptivity } \\
\left(\mathrm{m}^{*} \mathrm{~s}^{-0.5}\right)\end{array}$ \\
\hline 0.00 & 94.25 & 61.37 & 77.81 \\
\hline 0.10 & 82.94 & 67.79 & 75.37 \\
\hline 0.15 & 67.72 & 69.92 & 68.82 \\
\hline 0.20 & 64.42 & 68.70 & 66.56 \\
\hline 0.25 & 85.65 & 36.00 & 60.83 \\
\hline 0.30 & 54.97 & 61.56 & 58.27 \\
\hline 0.40 & 59.65 & 56.27 & 57.96 \\
\hline 0.50 & 55.49 & 61.36 & 58.43 \\
\hline
\end{tabular}




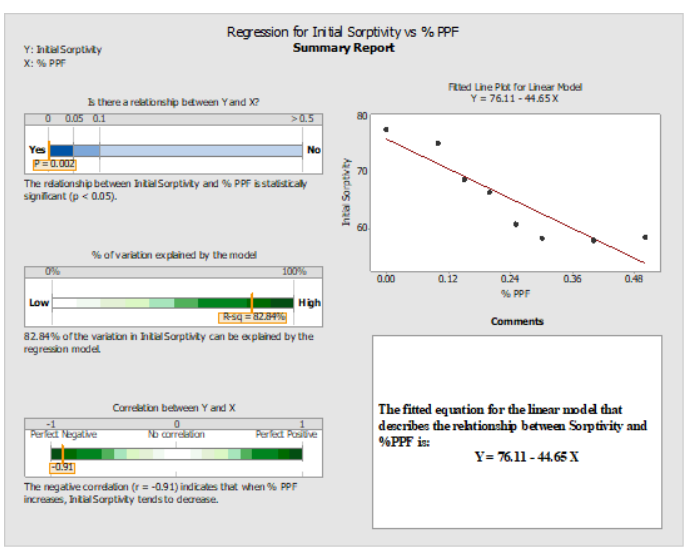

Figure 11. Average Initial Sorptivity of PFRC

\subsection{Acid Resistance Test}

\subsubsection{Visual Scrutiny}

The visual appearance of the GPC, OPC and PFRGC concrete specimens after being submerged in 5\% sulfuric acid solution for a period up to 56 days is shown through Fig. 12 to Fig. 20.

In case of OPC concrete the attack is more profound on the 28-day sample. The decomposition of $\mathrm{CaCO}_{3}$ to $\mathrm{CaCO}_{4}$ is indicated by the presence of streaks and white spots on the sample. This is evident from fig 12 to 14 . At 56 days' exposure, substantial surface erosion took place on the OPC concrete samples as more aggregates per unit area were visible on the concrete sample. This is evident in figure 14.

By looking at the impacts in the same condition, Fig. 15 to Fig. 17, GPC sample has been plainly influenced as demonstrated by obscured dark shading. In the case of geopolymer concrete sample exposed to 5\% sulfuric acid solution at different exposure period followings other observations were visualized:

1. Surface erosion was evident as the circumferential breaking of aggregates were seen

2. The penetration of acid into concrete is clearly evident from the fact that pores appeared on the surface of the concrete

3. More resistance to acid as compared to OPC.

The cube specimen of PFRGC, after exposure to $5 \%$ solution of $\mathrm{H}_{2} \mathrm{SO}_{4}$ is shown in Fig. 18 to Fig. 20. Efflorescence was observed on cubes surface of PFRGC which were more prominent at 28 and 56 days exposure to $5 \%$ solution of $\mathrm{H}_{2} \mathrm{SO}_{4}$. This is evident from Fig. 19 and Fig. 20. When the specimen was removed from the $\mathrm{H}_{2} \mathrm{SO}_{4}$ solution after 56 days Some minor spalling / leaching/ popping action of chemicals were observed was noted around the attacked area $(<1 \mathrm{~mm}$ thick), on closer look the leaching action was wet and more prominent. Efflorescence had encompassed $60 \%$ of the sample. Dissolving the efflorescence revealed spalling which made aggregate visible. However, the efflorescence was more widespread at 56 days of acid exposure. On visual scrutiny, erosion on the surface of the concrete cubes before the compression test the acid damage was seen on the outer $20 \mathrm{~mm}$ edges of the $150 \times 150 \times 150 \mathrm{~mm}$ test cubes. The results clearly indicate that PFRGC is more resistant to the acidic environment as compared to geopolymer concrete without fibre. This may be attributed to the fact that polypropylene fibre is resistant to alcohols, organic acids, esters and ketones and is highly resistant to most inorganic acids and alkalis. (Li et al.,2016).
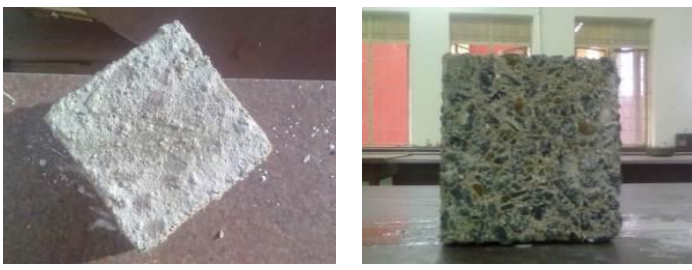

Figure 12. Visual Appearance of OPC Concrete after 14 Days Exposure in $5 \% \mathrm{H}_{2} \mathrm{SO}_{4}$ Solution
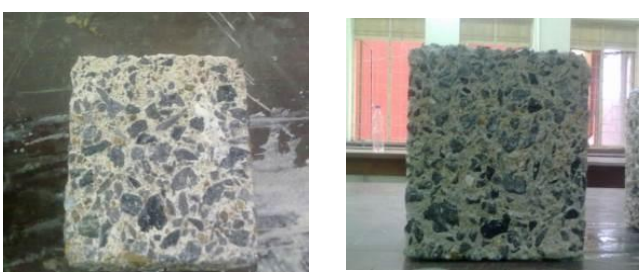

Figure 13. Visual Appearance of OPC Concrete after 28 Days Exposure In $5 \% \mathrm{H}_{2} \mathrm{SO}_{4}$ Solution
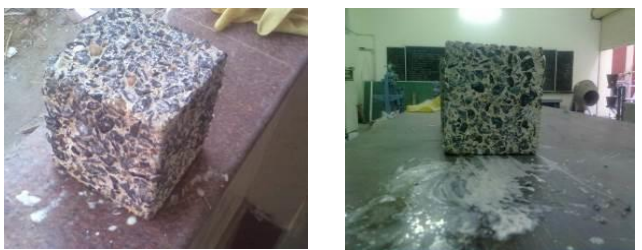

Figure 14. Visual Appearance of OPC Concrete after 56 Days Exposure In 5\% $\mathrm{H}_{2} \mathrm{SO}_{4}$ Solution
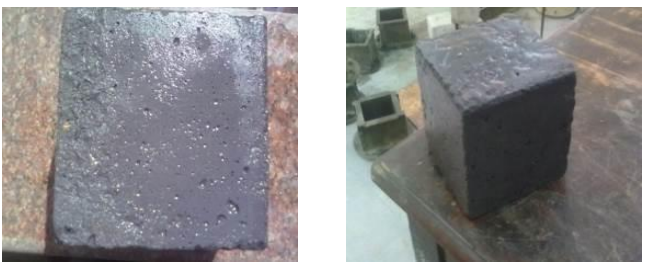

Figure 15. Visual Appearance of GPC Concrete after 14 Days Exposure In $5 \% \mathrm{H}_{2} \mathrm{SO}_{4}$ Solution
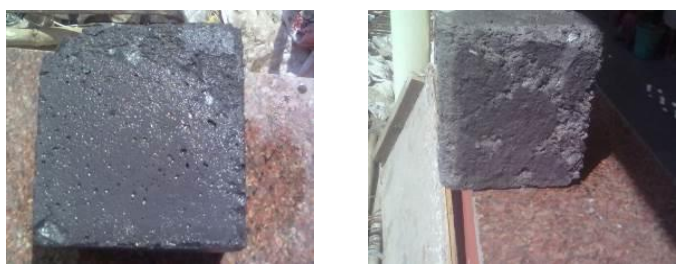

Figure 16. Visual Appearance of GPC Concrete after 28 Days Exposure In $5 \% \mathrm{H}_{2} \mathrm{SO}_{4}$ Solution 

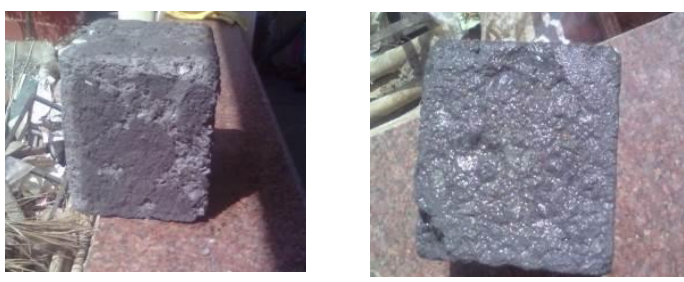

Figure 17. Visual Appearance of GPC Concrete after 56 Days Exposure In $5 \% \mathrm{H}_{2} \mathrm{SO}_{4}$ Solution
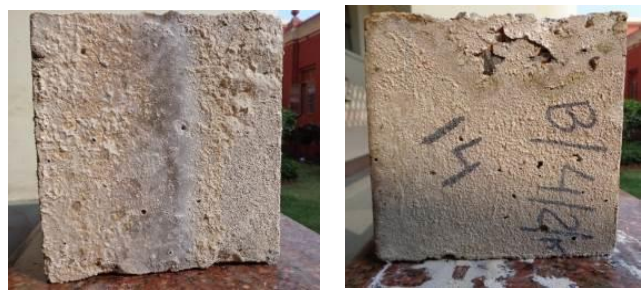

Figure 18. Visual Appearance of PFRGC after 14 Days Exposure In $5 \% \mathrm{H}_{2} \mathrm{SO}_{4}$ Solution
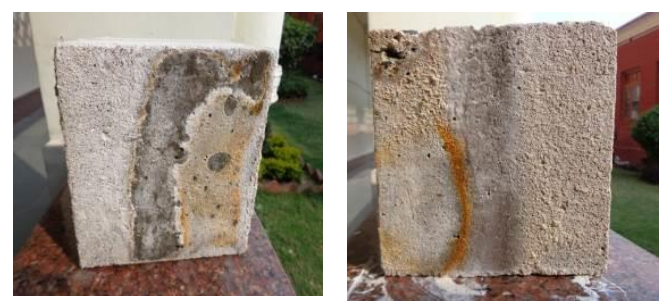

Figure 19. Visual Appearance of PFRGC after 28 Days Exposure In $5 \% \mathrm{H}_{2} \mathrm{SO}_{4}$ Solution
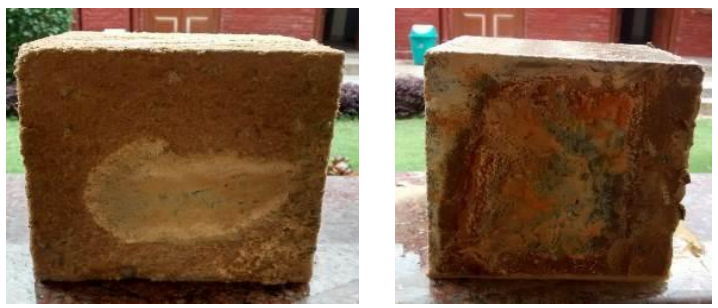

Figure 20. Visual Appearance of PFRGC after 56 Days Exposure In $5 \% \mathrm{H}_{2} \mathrm{SO}_{4}$ Solution

\subsubsection{Change in Weight of Concrete after Acid}

Attack

he percentage change in weight after acid exposure up to 56 days for both OPC and GPC concrete respectively are substantiated in the data table shown in Fig. 21. There was a small gain in weight during the first week of exposure this was also evident from the fact that when normal concrete is kept in water for curing there is gain in weight uphill seven days of curing.

Fig. 21 shows that the weight loss of FAGC was less than $3.5 \%$ after 56 days of exposure while weight loss was about $15 \%$ in the case of OPC concrete. The weight loss of FAGC and PFRGC is significantly small as compared to that of ordinary Portland cement concrete. The weight loss difference observed was the same for
PFRGC composites when compared to FAGC when exposed to a $5 \%$ solution of $\mathrm{H}_{2} \mathrm{SO}_{4}$.

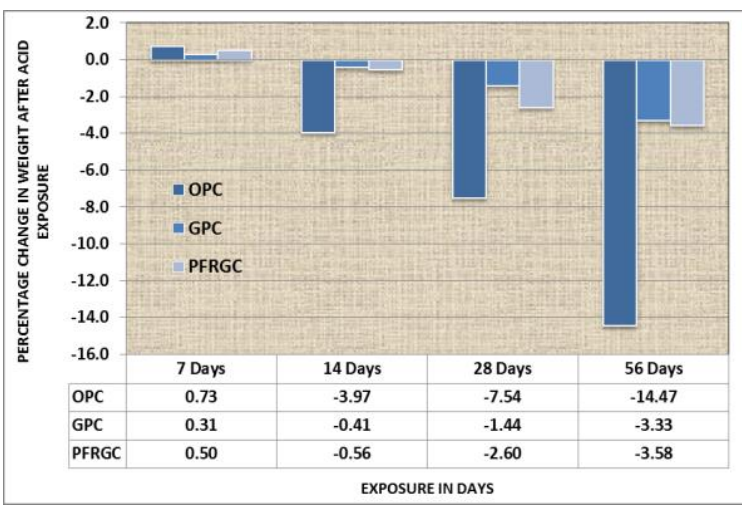

Figure 21. \% Loss in Weight after acid exposure

\subsubsection{Compressive Strength Test on Concrete after Acid Attack}

Cube specimens prepared for compressive strength were tested in laboratory and different crushing strengths when soaked in 5\%, the sulfuric acid solution at 7, 14, 28, and 56 days was found which are substantiated in Table 7.

Table 7 presents the variation in the compressive strength of GPC and OPC concrete and compares these results with reference to the compressive strength of unexposed specimens. The unexposed specimens of GPC were tested one day after oven curing, and ordinary Portland cement concrete was tested after 28 days of curing. Table 7 also summarizes the test data presented in terms of the compressive strength of FAGC, PFRGC and OPC concrete after being exposed to acid as a \% of the compressive strength of unexposed samples. It was observed that a decrease in compressive strength of OPC and FAGC increased as the period of exposure increased. However, the decrease was minimal in the case of PFRGC composites for all periods of exposure up to 56 days. As evident from Table 7, the loss in compressive strength of FAGC mix was about $13 \%$ after 56 days of exposure. This value was about $30 \%$ for ordinary Portland cement concrete exposed to $5 \% \mathrm{H}_{2} \mathrm{SO}_{4}$ solution. However, in the case of PFRGC composites, the loss in compressive strength observed was less than $10 \%$ after 56 days of acid exposure.

Fig. 22 presents the loss of compressive strength after acid exposure. On comparison of the test results of acid exposure, the loss in compressive strength of GPC was on an average 10 to $15 \%$ less when compared to OPC concrete after 56 days of exposure in normal water. The loss in compressive strength was almost $30 \%$ when the specimen of OPC concrete was exposed to $5 \%$ solution of $\mathrm{H}_{2} \mathrm{SO}_{4}$ for 56 days. However, the loss was about $10 \%$ in the case of polypropylene fibre based concrete. From the test results, it can also be inferred that polypropylene fibre reinforced concrete are more resistant to the acidic environment than normal concrete. 
Table 7. Results of Compressive Strength after Acid Exposure

\begin{tabular}{|c|c|c|c|c|c|c|}
\hline $\begin{array}{l}\text { Exposure } \\
\text { Period In } \\
\text { Days }\end{array}$ & $\begin{array}{c}\text { Compressive } \\
\text { Strength In MPa } \\
\text { For GPC }\end{array}$ & $\begin{array}{c}\% \text { Loss } \\
\text { In Strength }\end{array}$ & $\begin{array}{l}\text { Compressive } \\
\text { Strength In MPa } \\
\text { For OPC }\end{array}$ & $\begin{array}{c}\% \text { Loss } \\
\text { In Strength }\end{array}$ & $\begin{array}{c}\text { Compressive } \\
\text { Strength In MPa } \\
\text { For PFRGC }\end{array}$ & $\begin{array}{c}\% \text { Loss } \\
\text { In Strength }\end{array}$ \\
\hline 0 & 49.72 & 0.00 & 51.8 & 0.00 & 43.32 & 0.00 \\
\hline 7 & 48.48 & 2.50 & 48.26 & 6.83 & 42.65 & 1.55 \\
\hline 14 & 47.32 & 4.83 & 44.04 & 14.98 & 41.39 & 4.46 \\
\hline 28 & 46.09 & 7.30 & 38.62 & 25.44 & 40.78 & 5.86 \\
\hline 56 & 43.38 & 12.75 & 36.8 & 28.96 & 39.24 & 9.42 \\
\hline
\end{tabular}

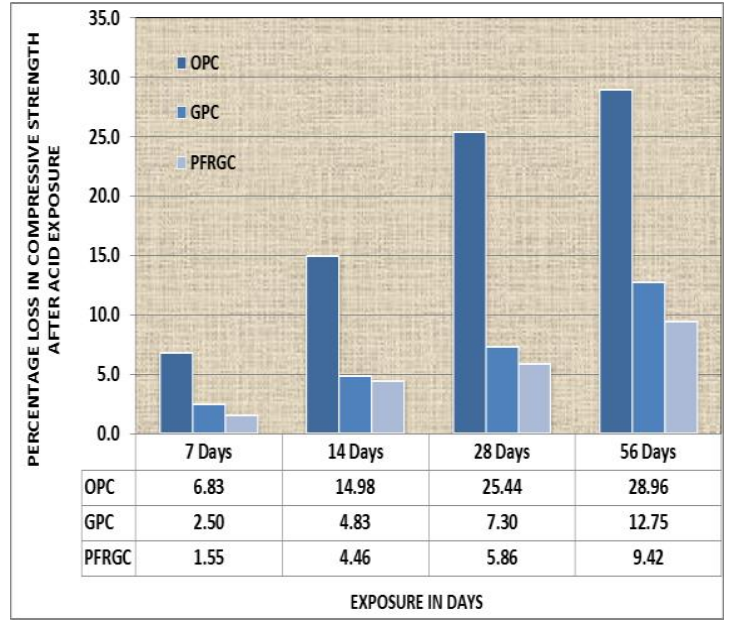

Figure 22. Loss of Compressive Strength after Acid Exposure

\section{CONCLUSIONS}

This paper presents a comprehensive experimental investigation of geopolymer concrete incorporating micro polypropylene fibre to assess the mechanical and durability properties. A comparative study of the test results has been carried out to study the influence of micro polypropylene fibre on FAGC. The following conclusions can be drawn:

1. The test results revealed that PPF has no significant effect on compressive strength of concrete. However, the performance of PFRGC has shown a significant improvement in split tensile strength when compared to normal geopolymer concrete without fibre addition.

2. The incorporation of Polypropylene fibre to geopolymer concrete changes the failure pattern from brittle mode to ductile, which displays the beneficial effects of FRC, used in structural engineering applications.

3. Incorporation of PPF in geopolymer concrete does not affect much the modulus of elasticity positively. This can be attributed to the low density of PP fibre, and further due to the possibility of formation of fibres balling during mixing which may have entrapped voids in the composite.

4. Sorptivity test result showed a significant reduction in capillary porosity when PPF are used in geopolymer concrete. The average initial sorptivity versus fibre volume fraction represents a linear relationship with a high $\mathrm{R}^{2}$ value. The result concludes that the decrease in sorptivity of polypropylene fibre based geopolymer concrete is favourable to the durability of the geopolymer concrete structure.

5. The surface erosion was observed on the outer 20 $\mathrm{mm}$ edges of the $150 \times 150 \mathrm{~mm}$ concrete cubes when immersed in the acid solution for 56 days. The weight loss of micro PFRGC as compared to that of OPC and GPC was less. Depletion in compressive strength of OPC, GPC and micro PFRGC increased as the period of exposure increased. The diminution in compressive strength was minimal in case of geopolymer concrete with polypropylene fibre for all periods of exposure up to 56 days thus indicating that PFRGC is more resistant to the acidic environment as compared to OPC and geopolymer concrete without fibre.

6. The usage of fly ash and micro PP fibre in geopolymer synthesis suggests a feasible approach to further enhancing the environmental benefits and solving the problems of substantial shrinkage and high brittleness.

\section{References:}

Ahmed, S.F.U., and Ronnie, Z. (2017). Ductile behavior of polyethylene fibre reinforced geopolymer composite: MATEC Web of Conferences, DOI: 10.1051/matecconf/20179701047.

Al-Tayyib, A.J., Al-Zahrani, M.M., R., and A., AlSulaimani, G.J. (1988). Effect of polypropylene fiber reinforcement on the properties of fresh and hardened concrete in the Arabian Gulf environment: Cement and Concrete Research, Vol. 18, No. 4, pp. 561-570.

Alhozaimy, A.M., Soroushian, P., and Mirza, F. (1996). Mechanical properties of polypropylene fiber reinforced concrete and the effects of pozzolanic materials: Cement and Concrete Composites, Vol. 18, No. 2, pp. 85-92, DOI: 10.1016/0958-9465(95)00003-8.

Alomayri, T., Shaikh, F.U.A., and Low, I.M. (2014). Synthesis and mechanical properties of cotton fabric reinforced geopolymer composites: Composites Part B: Engineering, Vol. 60, pp. 36-42, DOI: 10.1016/j.compositesb.2013.12.036. 
Alzeer, M., and MacKenzie, K.J.D. (2012). Synthesis and mechanical properties of new fibre-reinforced composites of inorganic polymers with natural wool fibres: Journal of Materials Science, Vol. 47, No. 19, pp. 6958-6965, DOI: 10.1007/s10853-012-6644-3.

Assaedi, H., Shaikh, F.U.A., and Low, I.M. (2016). Influence of mixing methods of nano silica on the microstructural and mechanical properties of flax fabric reinforced geopolymer composites: Construction and Building Materials, DOI: 10.1016/j.conbuildmat.2016.07.049.

ASTM C 1585 (2013). Standard Test Method for Measurement of Rate of Absorption of Water by Hydraulic-: ASTM International, pp. 4-9, DOI: 10.1520/C1585-13.2.

ASTM C 469 (2014). ASTM C469/C469M-14: Standard Test Method for Static Modulus of Elasticity and Poisson's Ratio of Concrete in Compression: Annual Book of ASTM Standards, DOI: 10.1520/C0469.

ASTM C293-02 (2002). Standard Test Method for Flexural Strength of Concrete (Using Simple Beam With Center-Point Loading): Annual Book of ASTM Standards, pp. 1-3, DOI: 10.1520/D1635.

Aulia, T.B. (2002). "Effects of polypropylene fibers on the properties of high-strength concretes." Institutes for Massivbau and Baustoffechnologi, University Leipzig, Lacer, p. 7.

Bagherzadeh, R., Pakravan, H.R., Sadeghi, A., Latifi, M., and Merati, A.A. (2012). An Investigation on Adding Polypropylene Fibers to Reinforce Lightweight Cement Composites (LWC): Journal of Engineered Fibers and Fabrics, Vol. 7, No. 4, pp. 13-21.

Banthia, N., and Gupta, R. (2006). Influence of polypropylene fiber geometry on plastic shrinkage cracking in concrete: Cement and Concrete Research, Vol. 36, pp. 1263-1267, DOI: 10.1016/j.cemconres.2006.01.010

Bernal, S., De Gutierrez, R., Delvasto, S., and Rodriguez, E. (2010). Performance of an alkali-activated slag concrete reinforced with steel fibers: Construction and Building Materials, Vol. 24, No. 2, pp. 208-214, DOI: 10.1016/j.conbuildmat.2007.10.027.

BRE (2000). Constructing the future: Design Build. Davidovits, J. (2005). Geopolymers: Journal of Thermal Analysis, DOI: 10.1007/bf01912193.

Davidovits, J. (1991). Geopolymers - Inorganic polymeric new materials: Journal of Thermal Analysis, Vol. 37, No. 8, pp. 1633-1656, DOI: 10.1007/BF01912193.

Davidovits, J. (1994). Properties of Geopolymer Cements: First International Conference on Alkaline Cements and Concretes, pp. 131-149.

Dias, D.P., and Thaumaturgo, C. (2005). Fracture toughness of geopolymeric concretes reinforced with basalt fibers: Cement and Concrete Composites, Vol. 27 , No. $1, \quad$ pp. 49-54, DOI: 10.1016/j.cemconcomp.2004.02.044

Fanella, D.A., and Naaman, A.E. (1985). Stress-strain Properties of Fiber Reinforced Mortar in Compression: ACI Journal, Vol. 82, No. 4, pp. 475-483, DOI: $10.14359 / 10359$

Fernández-Jiménez, A.M., Palomo, A., and LópezHombrados, C. (2006). Engineering properties of alkaliactivated fly ash concrete: ACI Materials Journal, Vol. 103, No. 2, pp. 106-112, DOI: 10.1111/j.17454530.2008.00353.x.

Gao, X., Yu, Q.L., Yu, R., and Brouwers, H.J.H. (2017). Evaluation of hybrid steel fiber reinforcement in high performance geopolymer composites: Materials and Structures/Materiaux et Constructions, DOI: 10.1617/s11527-017-1030-x.

Gong Yi, Sben Rongxi, L.Q. Application of Durafiber to Civil Architectural Engineering: Beijing: Machine Press, pp. 54-66.

Hardjito, D., Cheak, C.C., Ho, C., and Ing, L. (2008). Strength and Setting Times of Low Calcium Fly Ashbased Geopolymer Mortar: No. 1990, pp. 3-11.

Hardjito, D., and Rangan, B. V (2005). Development and Properties of Low Calcium Fly Ash based Geopolymer Concrete: Research Report GC 1 Faculty of Engineering Curtin University of Technology Perth, Australia.

He, P., Jia, D., Lin, T., Wang, M., and Zhou, Y. (2010). Effects of high-temperature heat treatment on the mechanical properties of unidirectional carbon fiber reinforced geopolymer composites: Ceramics International, Vol. 36, No. 4, pp. 1447-1453, DOI: 10.1016/j.ceramint.2010.02.012.

Heard, W.F., Basu, P.K., Slawson, T., and Nordendale, N.A. (2011). "Characterization and performance optimization of a cementitious composite for quasi-static and dynamic loads." Procedia Engineering.

Hua Yuan, Liu Ronghua, Z.Y. (1998). Experimental Study on High Performance Concrete Reinforced with Fiber: China Concrete and Cement Products, Vol. 3, pp. 40-43.

Hughes B.P., and Fattuhi., N.I. (1976). The Steel FibreReinforced Concrete: Magazine of Concrete Research, Vol. 28, No. 96, pp. 157-161.

IS: 516 (1959). Method of test for strength of concrete: Bureau of Indian Standards, New Delhi.

IS: 5816 (1999). Splitting Tensile Strength of Concrete Method of Test: Bureau of Indian Standard, New Delhi.

IS 10262:2009 (Ed.) Indian standards recommended Guidelines for concrete mix design, 2009th Ed., Bureau of Indian Standards.

IS 3812: Part 1 (2003). Pulverized Fuel Ash- 
Specification: Bureau of Indian Standards.

IS 383 (2016). Specification for Coarse and fine aggregates from natural sources for concrete. (IS 383:1970, Ed.): Bureau of Indian Standards.

Juenger, M.C.G., Winnefeld, F., Provis, J.L., and Ideker, J.H. (2011). Advances in alternative cementitious binders: Cement and Concrete Research, DOI: 10.1016/j.cemconres.2010.11.012.

Kalifa, P., Chéné, G., and Gallé, C. (2001). Hightemperature behaviour of HPC with polypropylene fibres - From spalling to microstructure: Cement and Concrete Research, Vol. 31, pp. 1487-1499, DOI: 10.1016/S00088846(01)00596-8.

Komonen, J., and Penttala, V. (2003). Effects of high temperature on the pore structure and strength of plain and polypropylene fiber reinforced cement pastes: Fire Technology, DOI: 10.1023/A:1021723126005.

Kuenzel, C., Vandeperre, L.J., Donatello, S., Boccaccini, A.R., and Cheeseman, C. (2012). Ambient temperature drying shrinkage and cracking in metakaolin-based geopolymers: Journal of the American Ceramic Society, Vol. 95, No. 10, pp. 3270-3277, DOI: 10.1111/j.15512916.2012.05380.x.

Li Guangwei, Y.Y. (2001). Experimental Study on Properties of Polypropylene Fiber Reinforced Concret: Advances in China Water Conservancy and Hydropower , ,() : 14-16, Vol. 21, No. 5, pp. 14-16.

Li, Z., Zhang, Y., Zhou, X., Behzad Nematollahi, Noushini, A., Hastings, M., Castel, A., Aslani, F., Olivia, M., Nikraz, H., López-Buendía, A.M., Romero-Sánchez, M.D., Climent, V., Guillem, C., Perera, D.S., et al. (2016). A Study of Utilization Aspect of Polypropylene Fibre for Making Value Added Concrete: Construction and Building Materials, Vol. 2, No. 2, pp. 103-106, DOI: 10.15373/22778179/feb2013/37.

Litvin, A. (1985). Properties of concrete containing polypropylene fibers. Report to Wire Reinforce Institute.: López-Buendía, A.M., Romero-Sánchez, M.D., Climent, V., and Guillem, C. (2013). Surface treated polypropylene (PP) fibres for reinforced concrete: Cement and Concrete Research, DOI: 10.1016/j.cemconres.2013.08.004.

Malhotra, V.M., Carette, G.G., and Bilodeau, A. (1994). Mechanical Properties and Durability of Polypropylene Fibre Reinforced High volume Fly Ash Concrete for Shotcrete Application: ACI Materials Journal, Vol. 91, No. 5, pp. 478-486.

Natali, A., Manzi, S., and Bignozzi, M.C. (2011). "Novel fiber-reinforced composite materials based on sustainable geopolymer matrix.” Procedia Engineering,, p. 11241131.

Nematollahi, B., Sanjayan, J., Qiu, J., and Yang, E.H. (2017). High ductile behavior of a polyethylene fiberreinforced one-part geopolymer composite: A micromechanics-based investigation: Archives of Civil and Mechanical Engineering, DOI: 10.1016/j.acme.2016.12.005

Nematollahi, B., Sanjayan, J., and Shaikh, F.U.A. (2015). Synthesis of heat and ambient cured one-part geopolymer mixes with different grades of sodium silicate: Ceramics International, Vol. 41, No. 4, pp. 5696-5704, DOI: 10.1016/j.ceramint.2014.12.154.

Olivia, M., and Nikraz, H. (2012). Properties of fly ash geopolymer concrete designed by Taguchi method: Materials and Design, Vol. 36, No. January 2011, pp. 191-198, DOI: 10.1016/j.matdes.2011.10.036.

Parviz Soroushian and Jer-Wen Hsu, A.K. (1992). Mechanical Properties of Concrete Materials Reinforced With Polypropylene or Polyethylene Fibers: ACI Materials Journal, Vol. 89, No. 6, DOI: 10.14359/4018.

Perera, D.S., Uchida, O., Vance, E.R., and Finnie, K.S. (2007). Influence of curing schedule on the integrity of geopolymers: Journal of Materials Science, Vol. 42, No. 9, pp. 3099-3106, DOI: 10.1007/s10853-006-0533-6.

Puertas, F., Amat, T., Fernández-Jiménez, A., and Vázquez, T. (2003). Mechanical and durable behaviour of alkaline cement mortars reinforced with polypropylene fibres: Cement and Concrete Research, Vol. 33, No. 12, pp. 2031-2036, DOI: 10.1016/S0008-8846(03)00222-9.

Rai, B., Roy, L.B., and Rajjak, M. (2018). A statistical investigation of different parameters influencing compressive strength of fly ash induced geopolymer concrete: Structural Concrete, DOI: 10.1002/suco.201700193.

Ranjbar, N., Mehrali, M., Behnia, A., Javadi Pordsari, A., Mehrali, M., Alengaram, U.J., and Jumaat, M.Z. (2016a). A Comprehensive Study of the Polypropylene Fiber Reinforced Fly Ash Based Geopolymer: PloS one, Vol. 11, No. 1, p. e0147546, DOI: 10.1371/journal.pone.0147546.

Ranjbar, N., Mehrali, M., Mehrali, M., Alengaram, U.J., and Jumaat, M.Z. (2015). Graphene nanoplatelet-fly ash based geopolymer composites: Cement and Concrete Research, Vol. 76, pp. 222-231, DOI: 10.1016/j.cemconres.2015.06.003.

Ranjbar, N., Mehrali, M., Mehrali, M., Alengaram, U.J., and Jumaat, M.Z. (2016b). High tensile strength fly ash based geopolymer composite using copper coated micro steel fiber: Construction and Building Materials, DOI: 10.1016/j.conbuildmat.2016.02.228.

Ranjbar, N., Talebian, S., Mehrali, M., Kuenzel, C., Cornelis Metselaar, H.S., and Jumaat, M.Z. (2016c). Mechanisms of interfacial bond in steel and polypropylene fiber reinforced geopolymer composites: Composites Science and Technology, Vol. 122, pp. 7381, DOI: 10.1016/j.compscitech.2015.11.009.

Reed, M., Lokuge, W., and Karunasena, W. (2014). Fibre-reinforced geopolymer concrete with ambient curing for in situ applications: Journal of Materials Science, Vol. 49, No. 12, pp. 4297-4304, DOI: 10.1007/s10853-014-8125-3. 
Richardson, A.E. (2006). Compressive strength of concrete with polypropylene fibre additions: Structural Survey, Vol. 24, No. 2, pp. 138-153, DOI: $10.1108 / 02630800610666673$.

Ridtirud, C., Chindaprasirt, P., and Pimraksa, K. (2011). Factors affecting the shrinkage of fly ash geopolymers: International Journal of Minerals, Metallurgy and Materials, Vol. 18, No. 1, pp. 100-104, DOI: 10.1007/s12613-011-0407-z.

Shaikh, F.U.A. (2013a). Deflection hardening behaviour of short fibre reinforced fly ash based geopolymer composites: Materials and Design, Vol. 50, pp. 674-682, DOI: 10.1016/j.matdes.2013.03.063.

Shaikh, F.U.A. (2013b). Review of mechanical properties of short fibre reinforced geopolymer composites: Construction and Building Materials, Vol. 43, pp. 37-49, DOI: 10.1016/j.conbuildmat.2013.01.026. Sofi, M., van Deventer, J.S.J., Mendis, P.A., and Lukey, G.C. (2007). Engineering properties of inorganic polymer concretes (IPCs): Cement and Concrete Research, Vol. 37, No. 2, pp. 251-257, DOI: 10.1016/j.cemconres.2006.10.008.

Song, P.S., and Hwang, S. (2004). Mechanical properties of high-strength steel fiber-reinforced concrete: Construction and Building Materials, Vol. 18, No. 9, pp. 669-673, DOI: 10.1016/j.conbuildmat.2004.04.027.

Tomkins, B.W. (2011). Chemical Resistance of Geopolymer Concrete Against $\mathrm{H} 2 \mathrm{SO} 4$ and $\mathrm{NaOH}$, p. 110.

Urbanova, M., Andertova, J., Brus, J., Vorel, J., Koloušek, D., and Hulinsky, V. (2007). Preparation, structure and hydrothermal stability of alternative (sodium silicate-free) geopolymers: Journal of Materials Science, Vol. 42, No. 22, pp. 9267-9275, DOI: 10.1007/s10853-007-1910-5.

Wallah, S.E., and Rangan, B. V (2006). Low-Cakcium Fly Ash Based.

Yost, J.R., Radlińska, A., Ernst, S., and Salera, M. (2013). Structural behavior of alkali activated fly ash concrete. Part .Mixture design, material properties and sample fabrication: Materials and Structures/Materiaux et Constructions, DOI: 10.1617/s11527-012-9919-x.

Yunsheng, Z., Wei, S., Zongjin, L., Xiangming, Z., Eddie, and Chungkong, C. (2008). Impact properties of geopolymer based extrudates incorporated with fly ash and PVA short fiber: Construction and Building Materials, Vol. 22, No. 3, pp. 370-383, DOI: 10.1016/j.conbuildmat.2006.08.006.

Zhang, Z., Yao, X., Zhu, H., Hua, S., and Chen, Y. (2009). Preparation and mechanical properties of polypropylene fiber reinforced calcined kaolin-fly ash based geopolymer: Journal of Central South University of Technology, Vol. 16, pp. 49-52, DOI: 10.1007/s11771-009-0008-4.

Zollo, R.F. Collated fibrillated polypropylene fibers in FRC, in G.C. Hoff (ed.) Fiber Reinforced Concrete: American Concrete Institute, Farmington Hills, MI, Vol. SP-81, pp. 397-409.

Zuhua, Z., Xiao, Y., Huajun, Z., and Yue, C. (2009). Role of water in the synthesis of calcined kaolin-based geopolymer: Applied Clay Science, Vol. 43, No. 2, pp. 218-223, DOI: 10.1016/j.clay.2008.09.003. 